Research Article

\title{
Heterogeneous Fenton Oxidation Using Magnesium Ferrite Nanoparticles for Ibuprofen Removal from Wastewater: Optimization and Kinetics Studies
}

\author{
Andrei Ivanets $\mathbb{D}^{1},{ }^{1}$ Vladimir Prozorovich, ${ }^{1}$ Marina Roshchina, \\ Inga Grigoraviciute-Puroniene, ${ }^{2}$ Aleksej Zarkov, ${ }^{2}$ Aivaras Kareiva, ${ }^{2}$ Zhao Wang, ${ }^{3}$ \\ Varsha Srivastava, ${ }^{4}$ and Mika Sillanpää $\mathbb{1}^{5,6,7}$ \\ ${ }^{1}$ Institute of General and Inorganic Chemistry of National Academy of Sciences of Belarus, St. Surganova 9/1, 220072 Minsk, Belarus \\ ${ }^{2}$ Institute of Chemistry, Vilnius University, Naugarduko 24, LT-03225 Vilnius, Lithuania \\ ${ }^{3}$ Department of Separation Science, Lappeenranta University of Technology, Sammonkatu, 12 Mikkeli, Finland \\ ${ }^{4}$ Department of Chemistry, University of Jyväskylä, P.O. Box 35, FI-40014 Jyväskylä, Finland \\ ${ }^{5}$ Institute of Research and Development, Duy Tan University, Da Nang 550000, Vietnam \\ ${ }^{6}$ Faculty of Environment and Chemical Engineering, Duy Tan University, Da Nang 550000, Vietnam \\ ${ }^{7}$ School of Civil Engineering and Surveying, Faculty of Health, Engineering and Sciences, University of Southern Queensland, \\ West Street, Toowoomba 4350, QLD, Australia
}

Correspondence should be addressed to Andrei Ivanets; ivanets@igic.bas-net.by and Mika Sillanpää; mikaetapiosillanpaa@duytan.edu.vn

Received 22 May 2020; Revised 12 August 2020; Accepted 26 August 2020; Published 16 September 2020

Academic Editor: Mohamed Bououdina

Copyright ( $) 2020$ Andrei Ivanets et al. This is an open access article distributed under the Creative Commons Attribution License, which permits unrestricted use, distribution, and reproduction in any medium, provided the original work is properly cited.

\begin{abstract}
In this study, the catalytic properties of Fenton-like catalyst based on magnesium ferrite nanoparticles for IBP degradation were examined. Structural and morphological studies showed the low crystallinity and mesoporous structure for the catalyst obtained via a glycine-nitrate method. The influences of catalyst dosage, oxidant concentration, and solution $\mathrm{pH}$ on the pollutant degradation were investigated. The pseudo-first-order model describes kinetic data, and under optimal condition (catalyst dose of $0.5 \mathrm{~g} \mathrm{~L}^{-1}, \mathrm{H}_{2} \mathrm{O}_{2}$ concentration of $20.0 \mathrm{mM}$, and $\mathrm{pH}$ of 8.0 ), apparent rate constant reached $0.091 \mathrm{~min}^{-1}$. It was shown that Fenton reaction was mainly induced by iron atoms on the catalyst surface, which is supported by very low iron leaching (up to $\left.0.05 \mathrm{mg} \mathrm{L}^{-1}\right)$ and high catalytic activity at neutral solution $\mathrm{pH}(6.0-8.0)$. It was found that the IBP mineralization onto magnesium ferrite catalyst was rapid and reached up to $98-100 \%$ within $40 \mathrm{~min}$. Thus, prepared magnesium ferrite nanoparticles can be used as an effective Fenton-like catalyst for the IBP degradation from wastewater.
\end{abstract}

\section{Introduction}

Ibuprofen (IBP) is a nonsteroidal anti-inflammatory drug, which is widely used to treat fever, pain, and inflammation of minor injury. IBP was the first member of propionic acid derivatives introduced in 1969. It is used as an analgesic and antipyretic drug for adults and children. IBP was rated as the safest conventional nonsteroidal anti-inflammatory drug by spontaneous adverse drug reaction reporting systems in the UK [1]. The high annual consumption is about 200 tons per year, and low metabolite conversion of IBP in the human body leads to the presence of IBP derivatives in the wastewater treatment plant, in surface water, and even in drinking water [2]. Ingestion of IBP in the environment leads to significant negative consequences. The municipal wastewater treatment plant, common water treatment processes, such as coagulation/flocculation and filtration, and biological treatment do not remove efficiently the pharmaceuticals and 
TABLE 1: Chemical structure and properties of ibuprofen (IBP) [21].

\begin{tabular}{|c|c|c|c|c|c|c|}
\hline Molecule structure image & CAS no. & Empirical formula & Molecular weight $\left(\mathrm{g} \mathrm{mol}^{-1}\right)$ & $\mathrm{pK}_{\mathrm{a}}$ & $\log \mathrm{K}_{\mathrm{ow}}$ & Solubility in water $\left(\mathrm{mg} \mathrm{L}^{-1}\right)$ \\
\hline & $15687-27-1$ & $\mathrm{C}_{13} \mathrm{H}_{18} \mathrm{O}_{2}$ & 206.29 & 5.3 & 3.97 & 21 \\
\hline
\end{tabular}

personal care products, which signifies the importance to develop new methods for removing these products from water bodies $[3,4]$.

Adsorption, sonolysis and sono-Fenton oxidation, photocatalytic oxidation, noncatalytic and catalytic ozonation, persulfate-based Advanced Oxidation Processes (AOPs), and heterogeneous Fenton processes are widely used for IBP removal from wastewater. The application of aforementioned methods is limited by their technical or economic disadvantages. Thus, adsorption methods are well suited for removing trace amounts of pharmaceuticals and cleaning relatively small volumes of water. Otherwise, the regeneration of the sorbent requires the destruction of sorbed toxic pharmaceuticals or their metabolites [5]. Electrochemical oxidation and ozonation belong to high-energy consumption methods, which is not always economically feasible. In addition, these methods are characterized by the formation of large quantities of oxidation products that are more toxic than the original pharmaceuticals $[6,7]$. Despite their attractiveness in the laboratory, photocatalytic methods are not widely used on an industrial scale $[8,9]$. This is due to their high sensitivity to the turbidity of wastewater, the complexity of the design of catalytic reactors that provide the necessary conditions for effective destruction of pollutants, and the need to use UV irradiation to achieve a high degree of mineralization of pharmaceutical contaminants $[10,11]$.

To avoid of these disadvantages, the application of heterogeneous catalyst based on iron oxides and metal ferrites is a promising solution [12]. Magnesium ferrite is a good candidate as an effective Fenton-like catalyst due to their affinity for various pollutants [13], high catalytic activity at a wide range of $\mathrm{pH}$ [14], and low metal ion leaching [15]. Therefore, magnesium ferrite has a high affinity towards inorganic and organic pollutants, which improved their catalytic efficiency due to concentration of the removed molecules in surface sites [16]. The degradation of Carbamazepine and Ciprofloxacin [17], Bisphenol A [18], and textile dyes [19, 20] onto metal ferrites such Fenton-like catalysts is widely reported. However, magnesium ferrite application for the degradation of pharmaceuticals is still limited.

In this paper, a nanostructured magnesium ferrite prepared by self-combustion sol-gel method was studied as heterogeneous Fenton-like catalyst for the IBP degradation. This work particularly evaluates the effects of the main AOP parameters: dose of catalyst, $\mathrm{H}_{2} \mathrm{O}_{2}$ oxidant concentration, and solution $\mathrm{pH}$ for optimization the IBP degradation. Also, kinetics parameters of the IBP degradation process were studied by means of HPLC technique and TOC analysis to establish the degree of IBP mineralization.

\section{Materials and Methods}

2.1. Chemical Reagents and Magnesium Ferrite Catalyst. Magnesium nitrate $\left(\mathrm{Mg}\left(\mathrm{NO}_{3}\right)_{2}\right)$, ferrous nitrate $\left(\mathrm{Fe}\left(\mathrm{NO}_{3}\right)_{3}\right)$, sodium chloride $(\mathrm{NaCl})$, and glycine $\left(\mathrm{H}_{2} \mathrm{NCH}_{2} \mathrm{COOH}\right)$ reagents were purchased from "Five Ocean" Corporation (Belarus) and used to obtain a catalyst based on magnesium ferrite nanoparticles. IBP (Table 1) and $\mathrm{H}_{2} \mathrm{O}_{2}$ solution 30 wt. \% were supplied by Sigma-Aldrich. All reagents were used as received without additional purification. Deionized water (resistance of $18.2 \mathrm{M} \Omega \cdot \mathrm{cm}^{-1}$ ) was used for the preparation of all aqueous solutions.

Magnesium ferrite nanoparticles were prepared by selfcombustion glycine-nitrate synthesis. Magnesium nitrate, ferrous nitrate, glycine, and sodium chloride as an inert additive were dissolved in deionized water in molar ratio $1: 2: 4.5: 10$, respectively. The prepared mixture was vaporized at $80^{\circ} \mathrm{C}$ under vigorous stirring before preparing a thick gel. Further, heating of the gel mass resulted in its spontaneous combustion. The obtained mixture of magnesium ferrite, coal, and sodium chloride was heated at $300^{\circ} \mathrm{C}$ for $5 \mathrm{~h}$. Magnesium ferrite nanoparticle was washed by deionized water and removed by a magnet. A detailed preparation method of magnesium ferrite has been previously reported [13].

2.2. Catalytic Experiments and Kinetics Modeling. Catalytic experiments were conducted in $50 \mathrm{~mL}$ centrifuge tubes at $20^{\circ} \mathrm{C}$ under natural light. Taking into account that IBP [21] is a weak acid $\left(\mathrm{pK}_{\mathrm{a}}=5.3\right)$ with low solubility in water $\left(21 \mathrm{mg} \mathrm{L}^{-1}\right)$ (Table 1$)$, the working IBP solution $\left(10 \mathrm{mg} \mathrm{L}^{-1}\right)$ was prepared by dissolution of the required powder sample in deionized water under vigorous stirring. In all experiments, IBP solutions were kept in the dark for 30 minutes after the addition of catalysts until the adsorption equilibrium was reached.

To determine the effect of the catalytic process conditions onto the efficiency of IBP $\left(10.0 \mathrm{mg} \mathrm{L}^{-1}\right)$ degradation, the dosage of catalyst $\left(0.2-1.0 \mathrm{~g} \mathrm{~L}^{-1}\right), \mathrm{H}_{2} \mathrm{O}_{2}$ concentration (10.0$\left.30.0 \mathrm{mmol} \mathrm{L}^{-1}\right), \mathrm{pH}$ of the solution (4.0-8.0), and contact time (5-40 minutes) were varied. For the evaluation the degree of IBP catalytic degradation and mineralization, $\mathrm{MgFe}_{2} \mathrm{O}_{4}$ catalyst with a given dosage of catalyst, $\mathrm{H}_{2} \mathrm{O}_{2}$ concentration was added to the IBP $\left(10.0 \mathrm{mg} \mathrm{L}^{-1}\right)$ aliquot of $50.0 \mathrm{~mL}$.

Preliminarily, it was checked that the addition of 10.0$30.0 \mathrm{mmol} \mathrm{L}^{-1} \mathrm{H}_{2} \mathrm{O}_{2}$ without catalyst did not result in IBP (10.0 $\mathrm{mg} \mathrm{L}^{-1}$ ) oxidation during 2 hours. Therefore, during the adsorption stage, IBP concentration was decreased on approximately $2-10 \%$ depending on the dosage of catalyst $\left(0.2-1.0 \mathrm{gL}^{-1}\right)$. These changes in IBP concentration were 
taken into account when calculating heterogeneous oxidation data. It should be noted that preliminary adsorption is a favorable process for efficient oxidation of organic pollutants [16]. After that, a required amount of $\mathrm{H}_{2} \mathrm{O}_{2}$ was added immediately into IBP/catalyst suspension and the catalytic process was initiated. At 5-, 10-, 20-, 30-, and 40-minute intervals, $5.0 \mathrm{~mL}$ solution containing solid catalyst particles were taken out and the liquid phase was separated by using a centrifuge (Model Eppendorf 5810R) with a speed of $5000 \mathrm{rpm}$ for 3 minutes for an IBP degradation efficiency test. According to empirical chemical reaction describing the fully IBP mineralization by $\mathrm{H}_{2} \mathrm{O}_{2}$ (Equation (1)), the stoichiometric amount of $\mathrm{H}_{2} \mathrm{O}_{2}\left(1.60 \mathrm{mmol} \mathrm{L}^{-1}\right)$ is much less than it was used in catalytic experiments.

$$
\mathrm{C}_{13} \mathrm{H}_{18} \mathrm{O}_{2}+33 \mathrm{H}_{2} \mathrm{O}_{2} \longrightarrow 13 \mathrm{CO}_{2}+42 \mathrm{H}_{2} \mathrm{O}
$$

The use of such an excessive amount of $\mathrm{H}_{2} \mathrm{O}_{2}$ may be due to the following: (i) low efficiency of reactive oxygen-containing spices (ROS) formation, (ii) low lifetime of OH-radicals, and (iii) fast recombination of produced hole-electron pairs [22]. The chosen interval of $\mathrm{H}_{2} \mathrm{O}_{2}$ concentration is in a good correlation with other results related to IBP heterogeneous Fenton oxidation [23]. All adsorption and catalytic experiments were repeated at least twice to ensure the reproducibility of the results.

The degradation efficiency $\alpha_{\text {HPLC }}$ and mineralization efficiency $\alpha_{\text {TOC }}$ of IBP were calculated according to

$$
\begin{aligned}
& \alpha_{\mathrm{HPLC}}=\frac{\left(C_{0}-C_{t}\right)}{C_{0}} \times 100 \%, \\
& \alpha_{\mathrm{TOC}}=\frac{\left(A_{0}-A_{t}\right)}{A_{0}} \times 100 \%,
\end{aligned}
$$

where $C_{0}$ and $C_{t}$ are the concentrations $\left(\mathrm{mg} \mathrm{L}^{-1}\right)$ of the IBP sample measured by high-performance liquid chromatography (HPLC) at initialt time (minutes) and $A_{0}$ and $A_{t}$ are the total organic carbon of the IBP sample at initial $t$ time (minutes), respectively.

Typically, the Fenton-like catalytic processes are usually well characterized by the Langmuir-Hinshelwood kinetic model, which describes a pseudo-first-order kinetics (Equation (3)) at low initial organic pollutant concentration [24].

$$
\ln \left(\frac{C_{0}}{C_{t}}\right)=k^{\prime} \times t,
$$

where $C_{0}$ and $C_{t}$ are the concentrations $\left(\mathrm{mg} \mathrm{L}^{-1}\right)$ of the IBP sample measured at initial $t$ time $(\mathrm{min})$ and $k^{\prime}$ is the apparent pseudo-first-order rate constant $\left(\mathrm{min}^{-1}\right)$.

\section{Analytical Methods}

The crystalline structure and phase analysis of magnesium ferrite nanoparticles were obtained using an X-ray diffractometer (PANalytical) with $\mathrm{K}_{\alpha}$ Co radiation $(\lambda=0.179 \mathrm{~nm})$. The domain size of prepared magnesium ferrite catalysts was calculated from the data of full-width at half-maximum (FWHM) of the (311) diffraction through the Scherrer equation.

$$
D=\frac{0.9 \times \lambda}{\beta \times \cos \theta},
$$

where $D$ is average particle size (nm), $\lambda$ is the wavelength of $\mathrm{K}_{\alpha}$ Co radiation, and $2 \theta$ and $\beta$ are the position (degree) and the half-width (radian) of the diffraction peak (311) in the experimental XRD patterns, respectively.

Fourier transform infra-red (FTIR) spectra of the catalyst were recorded on Bruker Vertex 70 FTIR in the range of a wavenumber of $400-4000 \mathrm{~cm}^{-1}$. Adsorption properties were evaluated by a nitrogen adsorption-desorption method $\left(-196^{\circ} \mathrm{C}\right)$ on a Micromeritics-Tristar II Plus specific surface area and porosity analyzer. A specific surface area $\left(A_{\mathrm{BET}}\right.$, $\left.\mathrm{m}^{2} \mathrm{~g}^{-1}\right)$ was calculated by the Brunauer-Emmett-Teller (BET) method. The total pore volume $\left(V_{\text {spdes }}\left(\mathrm{cm}^{3} \mathrm{~g}^{-1}\right)\right)$ was estimated at $p / p_{\mathrm{o}}=0.99$ using the Horvath-Kawazoe method. The average pore diameter $\left(D_{\text {sp des }}(\mathrm{nm})\right)$ was calculated by the equation $(4) \times 1000 \times V_{\mathrm{sp} \text { des }} / A_{\mathrm{BET}}$. The point of zero charge $\left(\mathrm{pH}_{\mathrm{pzc}}\right)$ was determined by the graphical drift method [25]. For this, $40 \mathrm{mg} \mathrm{MgFe}_{2} \mathrm{O}_{4}$ was placed in an aliquot of $10.0 \mathrm{~mL}$ and $0.01 \mathrm{M} \mathrm{NaCl}$ solution in the $\mathrm{pH}$ range of 3.0-12.0 and was stirred for 48 hours. Then, the sorbent was separated from the solution and the equilibrium $\mathrm{pH}$ value was measured.

The concentration of IBP in initial solution and treated solution was analyzed by high-performance liquid chromatography (HPLC-Shimadzu). Acetonitrile and potassium phosphate monobasic buffer $(50: 50, v / v)$ was used for the mobile phase, and the flow-rate was maintained at $1.0 \mathrm{~mL} \mathrm{~min}^{-1}$. A TOC analyzer (Shimadzu, Japan) was used for measuring IBP mineralization degree.

\section{Results and Discussion}

4.1. Characterization of Magnesium Ferrite Catalyst. As shown in Figure 1(a), the peaks in XRD spectra are referred to patterns of $\mathrm{MgFe}_{2} \mathrm{O}_{4}$ with cubic spinel structures. The peaks at $2 \theta$ values of $35.14^{\circ}, 41.46^{\circ}, 50.54^{\circ}, 67.37^{\circ}$, and $74.28^{\circ}$ belong to (202), (311), (400), (511), and (404) crystallographic planes of magnesium ferrite (JCPDS No. 96-9003804), respectively. The calculated parameter $a$ of the crystal lattice is $5.961 \AA$, which is different from the reference value for $\mathrm{MgFe}_{2} \mathrm{O}_{4}$ and may be due to a defect in the crystal structure of the resulting sample. The domain size of the prepared catalyst calculated from the Scherrer equation was about $2.2 \mathrm{~nm}$ (Table 2). The absorption peak on the IR spectrum (Figure 1(b)) at $547 \mathrm{~cm}^{-1}$ corresponds to the deformation vibrations of $\mathrm{Fe}-\mathrm{O}$ and $\mathrm{Mg}-\mathrm{O}$ for magnesium ferrite, which confirms the formation of $\mathrm{MgFe}_{2} \mathrm{O}_{4}$ with a cubic spinel structure [26]. Peaks at 1592 and $1454 \mathrm{~cm}^{-1}$ belong to the fluctuations of the hydroxyl group $\mathrm{O}-\mathrm{H}$, which largely determine the sorption properties of magnesium ferrite. The absorption band at 3337 and $3219 \mathrm{~cm}^{-1}$ refers to the valence vibrations of adsorbed water molecules. Texture parameters (BET surface area, pore volume, and average pore size) are listed in 


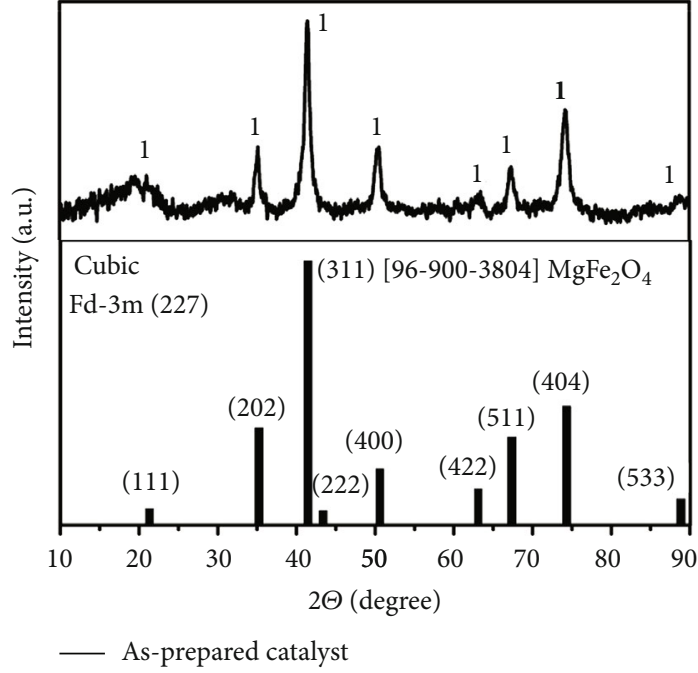

(a)

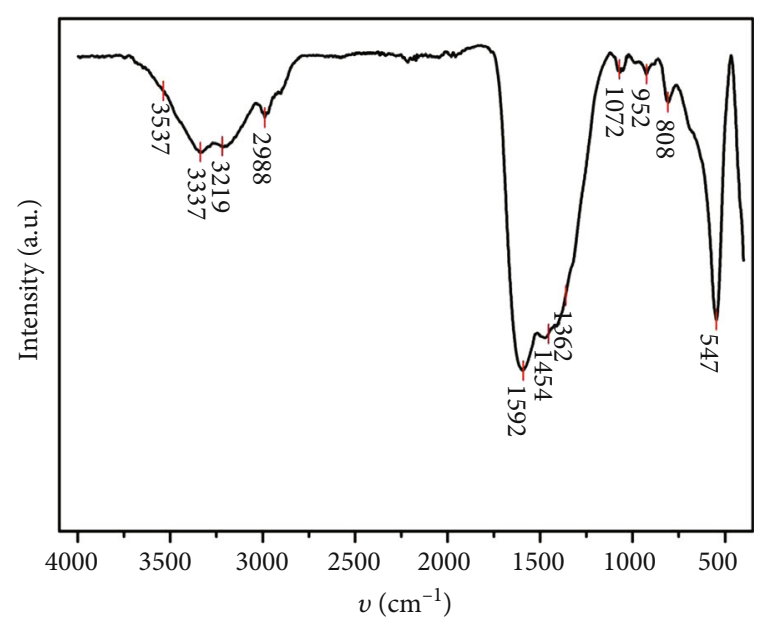

(b)

FIGURE 1: (a) XRD pattern and (b) FTIR spectra of magnesium ferrite catalyst.

TABLE 2: Structural, textural and surface properties of magnesium ferrite catalyst.

\begin{tabular}{lccccccc}
\hline Parameters of crystalline structure & \multicolumn{3}{c}{ Textural characteristics } & \multicolumn{3}{c}{ Surface chemistry } \\
Cell param. $a(\AA)$ & $D_{\text {Scherrer }}(\mathrm{nm})$ & Type of isotherm/hysteresis loop & $A_{\mathrm{BET}}\left(\mathrm{m}^{2} \mathrm{~g}^{-1}\right)$ & $V_{\text {sp des }}\left(\mathrm{cm}^{3} \mathrm{~g}^{-1}\right)$ & $D_{\text {sp des }}(\mathrm{nm})$ & $\begin{array}{c}\mathrm{pH} \\
\mathrm{pzc}\end{array}$ \\
\hline 5.961 & 2.2 & $\mathrm{IV} / \mathrm{H} 1$ & 14 & 0.037 & 11 & 6.58 \\
\hline
\end{tabular}

Table 2. The nitrogen isotherms of magnesium ferrite catalyst are related to type IV isotherms indicating its characteristic of mesoporous characteristics with $\mathrm{H} 1$ hysteresis loop corresponding to the cylindrical pore [27]. The BET surface area, pore volume, and average pore size of the catalyst were $14 \mathrm{~m}^{2} \mathrm{~g}^{-1}, 0.037 \mathrm{~cm}^{3} \mathrm{~g}^{-1}$, and $11 \mathrm{~nm}$, respectively. The $\mathrm{pH}_{\mathrm{pzc}}$ for the prepared catalyst was 6.58 (Table 2). It means that due to protonation of $\mathrm{M}-\mathrm{OH}(\mathrm{M}: \mathrm{Mg}$ or $\mathrm{Fe})$ groups in acidic solution, the surface of magnesium ferrite nanoparticles had positive charge. An increase of $\mathrm{pH}>6.58$ accompanied by dissociation of $\mathrm{M}-\mathrm{OH}$ groups, which leads to a change of the surface charge to negative. It is an important characteristic for the explanation of catalytic efficiency depends on the $\mathrm{pH}$ of IBP solution.

\subsection{Effect of Experimental Conditions on IBP Degradation}

4.2.1. Dose of Solid Catalyst. The kinetic curves of IBP degradation on magnesium ferrite nanoparticles as a function of catalyst dose are shown in Figure 2. The IBP degradation sharply increased with an increasing catalyst dose from 0.2 until an optimal value of $0.5 \mathrm{~g} \mathrm{~L}^{-1}$. A further increase of magnesium ferrite concentration up to $1.0 \mathrm{~g} \mathrm{~L}^{-1}$ was affected positively only at the first 20 minutes. Intrestingly, IBP degradation efficiency were equal for the catalytic reaction time of $30-40 \mathrm{~min}$. The increase of catalytic efficiency is dependent on the catalyst dose, but not proportionally. It is in accordance with the argument that the concentration of active catalytic sites on the surface of catalyst in the heterogeneous Fenton process for a dose of $0.5-1.0 \mathrm{~g} \mathrm{~L}^{-1}$ is a not limiting parameter for reactive oxygen spices producing. This

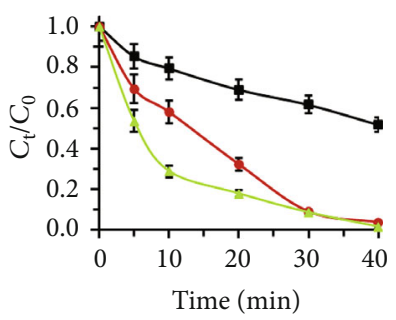

(a)

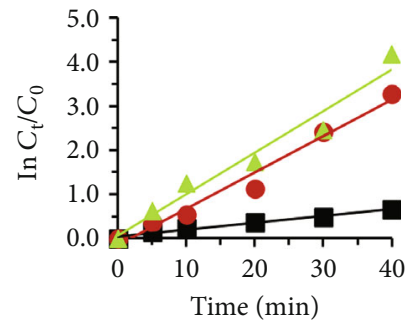

(b)

\begin{tabular}{cccc} 
& \multicolumn{3}{c}{ Dose of catalyst $\left(\mathrm{g} \mathrm{L}^{-1}\right)$} \\
\cline { 2 - 4 } Pseudo-first & 0.2 & 0.5 & 1.0 \\
\hline order & - & -6 & - \\
\hline$K^{\prime}\left(\min ^{-1}\right)$ & 0.019 & 0.070 & 0.099 \\
$R^{2}$ & 0.981 & 0.975 & 0.962 \\
\hline
\end{tabular}

FIgURE 2: (a) Kinetic curves and (b) pseudo-first-order linear plots of IBP degradation depend on magnesium ferrite catalyst doses. Experiment conditions: $\mathrm{C}\left(\mathrm{H}_{2} \mathrm{O}_{2}\right)=20 \mathrm{mM}$ and $\mathrm{pH}=8.0$.

observation is consistent with previous studies for the methylene blue degradation [16]. Compared to the homogenous Fenton process where the catalytic activity is dependent on ferrous/ferric ion concentration, the efficiency of the heterogeneous Fenton process mostly depends on the state of surface $\mathrm{Fe}-\mathrm{OH}$ sites. This is due to a low concentration of leached iron from a magnesium ferrite catalyst (less than $0.05 \mathrm{mg} \mathrm{L}^{-1}$ for catalyst dose of $\left.1.0 \mathrm{~g} \mathrm{~L}^{-1}\right)$. At the same time, higher differences in the rate of IBP degradation at the initial stage (up to 10 minutes) for different doses of catalysts 


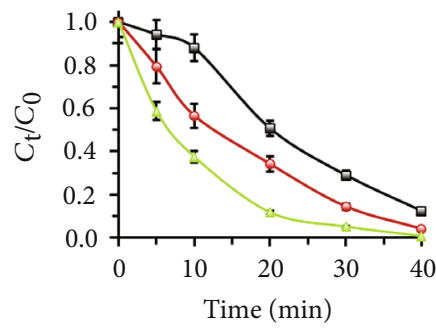

(a)

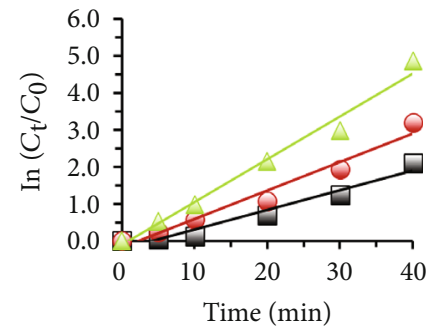

(b)

\begin{tabular}{cccc} 
& \multicolumn{3}{c}{$\mathrm{C}\left(\mathrm{H}_{2} \mathrm{O}_{2}\right)(\mathrm{mM})$} \\
\cline { 2 - 4 } Pseudo-first & 10.0 & 20.0 & 30.0 \\
order & $-\square$ & $-0-$ & $-\triangle$ \\
\hline$K^{\prime}\left(\mathrm{min}^{-1}\right)$ & 0.035 & 0.062 & 0.107 \\
$R^{2}$ & 0.954 & 0.968 & 0.983 \\
\hline
\end{tabular}

Figure 3: (a) Kinetic curves and (b) pseudo-first-order linear plots of IBP degradation depend on $\mathrm{H}_{2} \mathrm{O}_{2}$ concentrations. Experiment conditions: dose of catalyst $=0.5 \mathrm{gL}^{-1}$ and $\mathrm{pH}=8.0$.

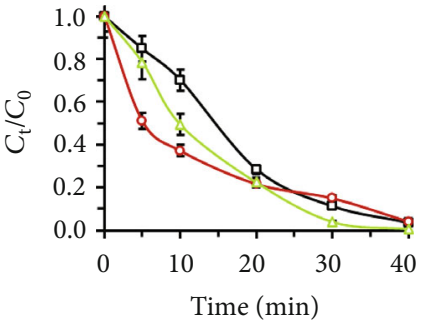

(a)

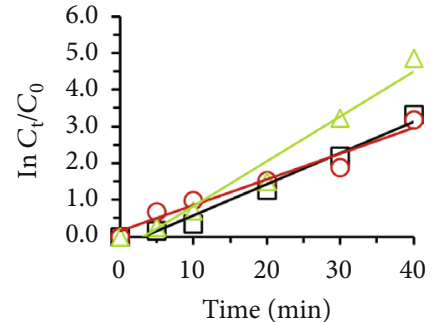

(b)

\begin{tabular}{cccc} 
Pseudo-first & \multicolumn{3}{c}{$\mathrm{pH}$} \\
\cline { 2 - 4 } order & 4.0 & 6.0 & 8.0 \\
& $-\square-$ & $-0-$ & $-\triangle$ \\
\hline$K^{\prime}\left(\mathrm{min}^{-1}\right)$ & 0.063 & 0.082 & 0.091 \\
$R^{2}$ & 0.977 & 0.958 & 0.967 \\
\hline
\end{tabular}

FIGURE 4: (a) Kinetic curves and (b) pseudo-first-order linear plots of IBP degradation depend on pH of solution. Experiment conditions: dose of catalyst $=0.5 \mathrm{gL}^{-1}$ and $\mathrm{C}\left(\mathrm{H}_{2} \mathrm{O}_{2}\right)=20 \mathrm{mM}$.

indicate the participation of leached iron ions in the catalytic process.

Based on the correlation coefficient $\left(R^{2}\right)$ in Figure 2, the pseudo-first-order model is the most suitable model describing the catalytic kinetics of IBP degradation on magnesium ferrite nanoparticles. The calculated apparent rate constants for 0.2 , 0.5 , and $1.0 \mathrm{gL}^{-1}$ dose were $0.019,0.070$, and $0.099 \mathrm{~min}^{-1}$, respectively. A higher number of catalytically active sites for $\mathrm{H}_{2} \mathrm{O}_{2}$ decomposition and reactive oxygen species generation could explain the positive effect of a solid catalyst.

4.2.2. $\mathrm{H}_{2} \mathrm{O}_{2}$ Concentration. It is well known that at high concentration $\mathrm{H}_{2} \mathrm{O}_{2}$ can act as scavenger of $\mathrm{OH}$ radicals (Equation (5)), reducing the efficiency of organic compounds catalytic degradation [28, 29]. Therefore, the efficiency of the heterogeneous Fenton process increases only until reaching optimal $\mathrm{H}_{2} \mathrm{O}_{2}$ concentration. For evaluating the optimum amount of $\mathrm{H}_{2} \mathrm{O}_{2}$, the IBP catalytic degradation tests were carried out for the initial concentration of 10.0, 20.0, and $30.0 \mathrm{mM}$.

$$
\cdot \mathrm{OH}+\mathrm{H}_{2} \mathrm{O}_{2} \longrightarrow \cdot \mathrm{OOH}+\mathrm{H}_{2} \mathrm{O}
$$

According to Figure 3, the rate of IBP degradation proportionally increased in a $10.0-30.0 \mathrm{mM} \mathrm{H}_{2} \mathrm{O}_{2}$ range. Increasing $\mathrm{H}_{2} \mathrm{O}_{2}$ concentration from 10.0 to $30.0 \mathrm{mM}$ was accompanied by an increase in the apparent pseudo-firstorder rate constant from 0.035 to $0.107 \mathrm{~min}^{-1}$. It should be noted that the used concentrations of $\mathrm{H}_{2} \mathrm{O}_{2}$ significantly exceeded the stoichiometric value required for the complete mineralization of IBP. It might result from the $\mathrm{H}_{2} \mathrm{O}_{2}$ decomposition without the production of $\mathrm{OH}$ radicals [30] or to the formation of small organic compounds exhibiting a slower rate constant for the radical attack [31].

4.2.3. $\mathrm{pH}$ of Model Solution. The $\mathrm{pH}$ of solution is the determining parameter that limits the efficiency of the homogeneous Fenton process. This is due to the existence of different forms of iron ions, such as ferric ions, mono- or polyhydroxy nuclear complexes, and colloidal particles. As a rule, the highest activity of the homogenous Fenton process reaches a $\mathrm{pH}$ of 2.8 [32], while heterogeneous Fenton reaction favored acidic and is close to neutral $\mathrm{pH}$ [33]. The influence of $\mathrm{pH}$ was investigated at close to neutral conditions $(\mathrm{pH}=4.0-8.0)$, while the IBP solution had $\mathrm{pH}=4.5$. The 


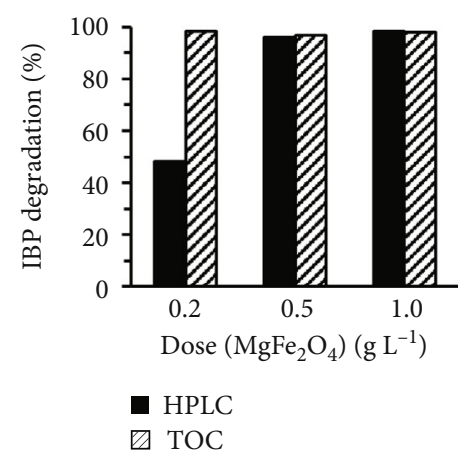

(a)

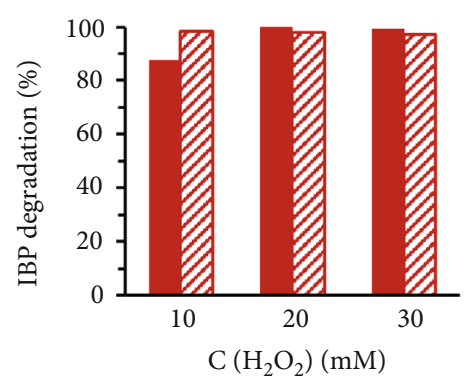

HPLC

$\square$ TOC

(b)

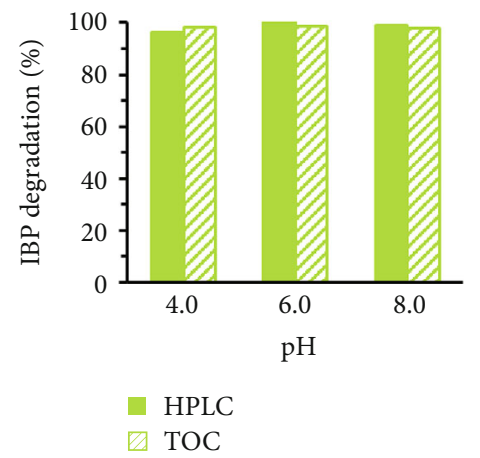

(c)

Figure 5: Effect of (a) doses of magnesium ferrite catalyst $\left(\mathrm{pH}=8.0, \mathrm{C}\left(\mathrm{H}_{2} \mathrm{O}_{2}\right)=20 \mathrm{mM}\right.$ ), (b) $\mathrm{H}_{2} \mathrm{O}_{2}$ concentrations ( $\mathrm{pH}=8.0$, dose of catalyst $\left.=0.5 \mathrm{~g} \mathrm{~L}^{-1}\right)$ and (c) $\mathrm{pH}$ of solution (dose of catalyst $=0.5 \mathrm{~g} \mathrm{~L}^{-1}, \mathrm{C}\left(\mathrm{H}_{2} \mathrm{O}_{2}\right)=20 \mathrm{mM}$ ) on degree of IBP degradation and mineralization. Contact time for all data is 40 minutes.

range of $\mathrm{pH}$ was chosen close to real wastewater from pharmaceutical plants [34].

According to Figure 4, the highest IBP degradation efficiency $k^{\prime}=0.082$ and reaction time $=0.091 \mathrm{~min}^{-1}$ were performed at neutral (6.0) and slightly alkaline (8.0) $\mathrm{pH}$, respectively. Taking into account IBP pKa $=5.3$ (Table 1) and magnesium ferrite $\mathrm{pH}_{\mathrm{pzc}}=6.58$ (Table 2), at this $\mathrm{pH}$ range, IBP is present in an anionic form and catalysts have negative charge leading to electrostatic repulsion. It means that the active sites of catalyst do not occur by IBP and free for interaction with $\mathrm{H}_{2} \mathrm{O}_{2}$. Similar results were obtained for methylene blue degradation on magnesium ferrite catalyst [16].

4.3. Evaluation of IBP Degradation and Mineralization. Generally, IBP degradation was accompanied by the formation of various byproducts. Adityosulindro et al. [23] reported about up 14 transformation products of IBP (1-hydroxy IBP, 2hydroxy-IBP, 4-isobutylacetophenon, etc.) during Fenton oxidation on $\mathrm{Fe}$-containing zeolite. This result correlates with a low IBP mineralization degree that is less than 0.6 according to TOC analysis. To confirm the effectiveness of IBP mineralization on magnesium ferrite Fenton catalyst, the comparison data of HPLC and TOC analyses are shown in diagrams (Figure 5) for model solution after 40-minute reaction. The effect of doses of magnesium ferrite catalyst, $\mathrm{H}_{2} \mathrm{O}_{2}$ concentrations, and $\mathrm{pH}$ of the solutions on degree of IBP degradation and mineralization were studied. It is extremely important to note that for all experimental condi- tions, the IBP mineralization degree was close to $98-100 \%$. Only for the lowest dose of magnesium ferrite catalyst $\left(0.2 \mathrm{~g} \mathrm{~L}^{-1}\right)$ and $\mathrm{H}_{2} \mathrm{O}_{2}$ concentration $(10.0 \mathrm{mM})$ differences in HPLC and TOC data were observed (Figures 5(a) and 5(b)), when IBP mineralization degrees were about 48 and $88 \%$, respectively.

4.4. Comparison with Fenton-Like Catalysts and Photocatalysts. Comparative data on the catalytic IBP degradation (Table 3) show that magnesium ferrite demonstrates high catalytic activity and exceeds many Fenton-like catalysts and photocatalysts in terms of the apparent rate constant. An important advantage of the obtained catalyst is the high rate of IBP oxidation. Almost complete mineralization was achieved within $40 \mathrm{~min}$, while the other catalysts require time from 60 to $180 \mathrm{~min}$, which is important for practical application. The relatively high initial concentration of $\mathrm{H}_{2} \mathrm{O}_{2}$ used in this work is due to performing the catalytic process under natural light and the high IBP concentration in the model solutions. The main advantage of the developed Fenton-like catalyst is the complete IBP mineralization during their oxidative degradation.

\section{Conclusions}

Fenton-like catalyst based on magnesium ferrite nanoparticles characterized by low crystallinity (lattice parameter $a$ of $5.961 \AA$, crystallite size of $2.2 \mathrm{~nm}$ ) and mesoporous structure 
TABLE 3: Comparison data of apparent pseudo-first-order rate constant $\left(k^{\prime}\right)$ for IBP degradation using various Fenton-like catalysts and photocatalysts.

\begin{tabular}{|c|c|c|c|}
\hline Catalysts & Conditions & $k^{\prime}, \min ^{-1}$ & References \\
\hline $\begin{array}{l}\mathrm{TiO}_{2} \\
\mathrm{TiO}_{2} \text {-boron nitride nanocomposite }\end{array}$ & $\begin{array}{c}{[\text { catalyst }]=0.1 \mathrm{~g} \mathrm{~L}^{-1},[\mathrm{IBP}]=5 \mathrm{mg} \mathrm{L}^{-1}, \mathrm{pH}=7.0} \\
\mathrm{UV} \text { light irradiation, } t=180 \mathrm{~min}\end{array}$ & $\begin{array}{l}0.047 \\
0.054\end{array}$ & {$[10]$} \\
\hline Fe-zeolite catalyst (of ZSM5 type) & $\begin{array}{c}{[\text { catalyst dose }]=4.8 \mathrm{~g} \mathrm{~L}^{-1},\left[\mathrm{H}_{2} \mathrm{O}_{2}\right]=6.4 \mathrm{mM}, \mathrm{pH}=4.3} \\
{[\mathrm{IBP}]=20 \mathrm{mg} \mathrm{L}^{-1}, T=25^{\circ} \mathrm{C}, t=180 \mathrm{~min}}\end{array}$ & 0.014 & {$[23]$} \\
\hline Recycled rusted iron particles & $\begin{array}{c}{[\text { catalyst dose }]=0.25 \mathrm{~g} \mathrm{~L}^{-1},[\mathrm{PDS}]=0.5 \mathrm{mM}, \mathrm{pH}=7.0} \\
{[\mathrm{IBP}]=10 \mu \mathrm{g} \mathrm{L}^{-1}, T=25^{\circ} \mathrm{C}, t=30 \mathrm{~min}}\end{array}$ & 0.140 & {$[35]$} \\
\hline Zeolite- $\mathrm{TiO}_{2}$-UV/ultrasound $/ \mathrm{H}_{2} \mathrm{O}_{2}$ & $\begin{array}{c}{[\text { catalyst dose }]=1.5 \mathrm{~g} \mathrm{~L}^{-1},\left[\mathrm{H}_{2} \mathrm{O}_{2}\right]=0.05 \mathrm{mM}, \mathrm{pH}=5.0} \\
T=20^{\circ} \mathrm{C}, t=120 \mathrm{~min}, \mathrm{UV} \text { power }=6 \mathrm{~W}\end{array}$ & 0.031 & {$[36]$} \\
\hline $\begin{array}{l}\text { Ultrasound/BaTiO }{ }_{3} \text { nanowires/piezoelectric } \\
\text { catalytic persulfate }\end{array}$ & $\begin{array}{c}{[\text { catalyst dose }]=2.0 \mathrm{~g} \mathrm{~L}^{-1},[\mathrm{PS}]=1.0 \mathrm{mM}} \\
{[\mathrm{IBP}]=6.0 \mathrm{mg} \mathrm{L}^{-1}, t=60 \mathrm{~min}}\end{array}$ & 0.082 & {$[37]$} \\
\hline $\mathrm{Co}_{3} \mathrm{O}_{4}: \mathrm{Bi}(1: 2)$ nanocomposite & $\begin{array}{c}{[\text { catalyst dose }]=0.8 \mathrm{~g} \mathrm{~L}^{-1},[\mathrm{IBP}]=10.0 \mathrm{mg} \mathrm{L}^{-1}, \mathrm{pH}=11.3} \\
T=20^{\circ} \mathrm{C}, t=60 \mathrm{~min} \text {, visible light irradiation }\end{array}$ & 0.094 & {$[38]$} \\
\hline $\begin{array}{l}\mathrm{TiO}_{2} / \mathrm{UV} \\
\mathrm{g}-\mathrm{C}_{3} \mathrm{~N}_{4} / \mathrm{Vis}\end{array}$ & $\begin{array}{c}{[\text { catalyst dose }]=2.7 \mathrm{~g} \mathrm{~L}^{-1},[\mathrm{IBP}]=5.0 \mu \mathrm{g} \mathrm{L}^{-1}, \mathrm{pH}=5.1} \\
T=25^{\circ} \mathrm{C}, t=10 \mathrm{~min}, \mathrm{UV} \text { power }=15 \mathrm{~W} \\
{[\text { catalyst dose }]=0.8 \mathrm{~g} \mathrm{~L}^{-1},[\mathrm{IBP}]=5.0 \mu \mathrm{g} \mathrm{L}-1, \mathrm{pH}=2.5} \\
T=25^{\circ} \mathrm{C}, t=120 \mathrm{~min}, \mathrm{LED} \text { power }=10 \mathrm{~W}\end{array}$ & $\begin{array}{l}1.000 \\
0.030\end{array}$ & [39] \\
\hline $\mathrm{FeO}_{\mathrm{x}}-\mathrm{MnO}_{\mathrm{x}} / \mathrm{SBA}-15$ & $\begin{aligned} {[\text { catalyst dose }]=} & 1.0 \mathrm{~g} \mathrm{~L}^{-1},[\text { Oxone }]=6.25 \mathrm{mM},[\mathrm{IBP}]=24.2 \mu \mathrm{g} \mathrm{L}^{-1}, \\
& \mathrm{pH}=6.4, T=25^{\circ} \mathrm{C}, t=175 \mathrm{~min}\end{aligned}$ & 0.032 & {$[40]$} \\
\hline $10 \mathrm{wt} \% \mathrm{~g}-\mathrm{C}_{3} \mathrm{~N}_{4} / \mathrm{MIL}-68(\mathrm{In})-\mathrm{NH}_{2}$ & $\begin{array}{c}{[\text { catalyst dose }]=0.15 \mathrm{~g} \mathrm{~L}^{-1},[\mathrm{IBP}]=20.0 \mathrm{mg} \mathrm{L}^{-1}, \mathrm{pH}=4.0} \\
T=25^{\circ} \mathrm{C}, t=120 \mathrm{~min}, \mathrm{LED} \text { power }=300 \mathrm{~W}\end{array}$ & 0.017 & {$[41]$} \\
\hline $\mathrm{MgFe}_{2} \mathrm{O}_{4}$ & $\begin{array}{c}{[\text { catalyst dose }]=0.5 \mathrm{~g} \mathrm{~L}^{-1},\left[\mathrm{H}_{2} \mathrm{O}_{2}\right]=20.0 \mathrm{mM},[\mathrm{IBP}]=10.0 \mathrm{mg} \mathrm{L}^{-1},} \\
\mathrm{pH}=8.0, T=20^{\circ} \mathrm{C}, t=40 \mathrm{~min}\end{array}$ & 0.091 & This study \\
\hline
\end{tabular}

(BET specific area of $14 \mathrm{~m}^{2} \mathrm{~g}^{-1}$, sorption volume of $0.030 \mathrm{~cm}^{3} \mathrm{~g}^{-1}$, and average pore size of $11 \mathrm{~nm}$ ) was synthesized. The influence of the conditions of the catalytic process (dose of catalyst, $\mathrm{H}_{2} \mathrm{O}_{2}$ concentration, and $\mathrm{pH}$ of solution) on the efficiency of nonsteroidal anti-inflammatory drug IBP degradation was established. The reaction followed the pseudo-first-order kinetics with respect to IBP, and the apparent rate constant increased almost proportionally with catalyst loading and $\mathrm{H}_{2} \mathrm{O}_{2}$ concentration. It was shown that at the catalyst dose of $0.5 \mathrm{~g} \mathrm{~L}^{-1}, \mathrm{H}_{2} \mathrm{O}_{2}$ concentration of $20.0 \mathrm{mM}$, and $\mathrm{pH}$ of 8.0 for $40 \mathrm{~min}$, the IBP concentration from $10.0 \mathrm{mg} \mathrm{L}^{-1}$ achieved less than detected limit and the IBP mineralization reached 98-100\%. The conducted research has shown the prospects of the practical application of the developed Fenton-like heterogeneous catalyst for wastewater treatment from pharmaceutically active compounds.

\section{Data Availability}

The manuscript data used to support the findings of this study are included within the article.

\section{Conflicts of Interest}

The authors declare that there is no conflict of interest regarding the publication of this paper.

\section{Acknowledgments}

This work was financially supported by Belarusian Republican Foundation for Fundamental Research (No. X19LITG007) and Research grant NOCAMAT (No. S-LB-19-2) from the Research Council of Lithuania. The authors are grateful to MOST Programme for the scholarships of Andrei Ivanets (No. R-wY4k-52961) and Vladimir Prozorovich (No. R-Jae252969) and to the World Federation of Scientists for the scholarship of Vladimir Prozorovich (Belarus National Scholarship Programme).

\section{References}

[1] R. Bushra and N. Aslam, "An overview of clinical pharmacology of ibuprofen,” Oman Medical Journal, vol. 25, no. 3, pp. 155-161, 2010.

[2] S. Fekadu, E. Alemayehu, R. Dewil, and B. Van der Bruggen, "Pharmaceuticals in freshwater aquatic environments: a comparison of the African and European challenge," Science of the Total Environment, vol. 654, pp. 324-337, 2019.

[3] A. Jelic, M. Gros, A. Ginebreda et al., "Occurrence, partition and removal of pharmaceuticals in sewage water and sludge during wastewater treatment," Water Research, vol. 45, no. 3, pp. 1165-1176, 2011.

[4] A. Courtier, A. Cadiere, and B. Roig, "Human pharmaceuticals: why and how to reduce their presence in the environment," Current Opinion in Green and Sustainable Chemistry, vol. 15, pp. 77-82, 2019. 
[5] M. J. Ahmed, "Adsorption of non-steroidal anti-inflammatory drugs from aqueous solution using activated carbons: review," Journal of Environmental Management, vol. 190, pp. 274-282, 2017.

[6] C.-H. Hung, C. Yuan, M.-H. Wu, and Y.-C. Chang, "Electrochemical degradation of ibuprofen-contaminated soils over $\mathrm{Fe} / \mathrm{Al}$ oxidation electrodes," Science of the Total Environment, vol. 640-641, pp. 1205-1213, 2018.

[7] S. Saeid, P. Tolvanen, N. Kumar et al., "Advanced oxidation process for the removal of ibuprofen from aqueous solution: a non-catalytic and catalytic ozonation study in a semi-batch reactor," Applied Catalysis B: Environmental, vol. 230, pp. 77-90, 2018.

[8] N. Fu, X.-C. Ren, and J.-X. Wan, "The effect of molar ratios of $\mathrm{Ti} / \mathrm{Si}$ on core-shell SiO2@TiO2Nanoparticles for photocatalytic applications," Journal of Nanomaterials, vol. 2020, Article ID 5312376, 11 pages, 2020.

[9] Z. Wang, V. Srivastava, I. Ambat, Z. Safaei, and M. Sillanpää, "Degradation of Ibuprofen by UV-LED/catalytic advanced oxidation process," Journal of Water Process Engineering, vol. 31, article 100808, 2019.

[10] L. Lin, W. Jiang, M. Bechelany et al., "Adsorption and photocatalytic oxidation of ibuprofen using nanocomposites of $\mathrm{TiO}_{2}$ nanofibers combined with $\mathrm{BN}$ nanosheets: degradation products and mechanisms," Chemosphere, vol. 220, pp. 921929, 2019.

[11] A. Raja, P. Rajasekaran, K. Selvakumar, M. Arivanandhan, S. Asath Bahadur, and M. Swaminathan, "Rational fabrication of needle with spherical shape ternary reduced Graphene Oxide- $\mathrm{HoVO}_{4}-\mathrm{TiO}_{2}$ photocatalyst for degradation of ibuprofen under visible light," Applied Surface Science, vol. 513, article $145803,2020$.

[12] K. K. Kefeni, B. B. Mamba, and T. A. M. Msagati, “Application of spinel ferrite nanoparticles in water and wastewater treatment: a review," Separation and Purification Technology, vol. 188, pp. 399-422, 2017.

[13] A. I. Ivanets, V. Srivastava, M. Y. Roshchina, M. Sillanpää, V. G. Prozorovich, and V. V. Pankov, "Magnesium ferrite nanoparticles as a magnetic sorbent for the removal of $\mathrm{Mn}^{2+}$, $\mathrm{Co}^{2+}, \mathrm{Ni}^{2+}$ and $\mathrm{Cu}^{2+}$ from aqueous solution," Ceramics International, vol. 44, no. 8, pp. 9097-9104, 2018.

[14] L. T. T. Nguyen, L. T. H. Nguyen, N. C. Manh et al., "A facile synthesis, characterization, and photocatalytic activity of magnesium ferrite nanoparticles via the solution combustion method," Journal of Chemistry, vol. 2019, Article ID 3428681, 8 pages, 2019.

[15] S. I. Hussein, A. S. Elkady, M. M. Rashad, A. G. Mostafa, and R. M. Megahid, "Structural and magnetic properties of magnesium ferrite nanoparticles prepared via EDTA-based sol-gel reaction," Journal of Magnetism and Magnetic Materials, vol. 379, pp. 9-15, 2015.

[16] A. Ivanets, M. Roshchina, V. Srivastava et al., "Effect of metal ions adsorption on the efficiency of methylene blue degradation onto $\mathrm{MgFe}_{2} \mathrm{O}_{4}$ as Fenton-like catalysts," Colloids and Surfaces A: Physicochemical and Engineering Aspects, vol. 571, pp. 17-26, 2019.

[17] D. Hermosilla, C. Han, M. N. Nadagouda et al., "Environmentally friendly synthesized and magnetically recoverable designed ferrite photo-catalysts for wastewater treatment applications," Journal of Hazardous Materials, vol. 381, article 121200, 2020.
[18] M. Rani, Rachna, and U. Shanker, "Efficient photocatalytic degradation of Bisphenol A by metal ferrites nanoparticles under sunlight," Environmental Technology \& Innovation, vol. 19, article 100792, 2020.

[19] X. Han, H. Zhang, T. Chen, M. Zhang, and M. Guo, "Facile synthesis of metal-doped magnesium ferrite from saprolite laterite as an effective heterogeneous Fenton-like catalyst," Journal of Molecular Liquids, vol. 272, pp. 43-52, 2018.

[20] S. Singh and S. Singhal, "Transition metal doped cobalt ferrite nanoparticles: efficient photocatalyst for photodegradation of textile dye," Materials Today: Proceedings, vol. 14, Part 2, pp. 453-460, 2019.

[21] ational Center for Biotechnology Information, "PubChem Database. Ibuprofen, CID = 3672," April 2020, https:// pubchem.ncbi.nlm.nih.gov/compound/Ibuprofen.

[22] M. Sillanpää, M. C. Ncibi, and A. Matilainen, "Advanced oxidation processes for the removal of natural organic matter from drinking water sources: a comprehensive review," Journal of Environmental Management, vol. 208, pp. 56-76, 2018.

[23] S. Adityosulindro, C. Julcour, and L. Barthe, "Heterogeneous Fenton oxidation using Fe-ZSM5 catalyst for removal of ibuprofen in wastewater," Journal of Environmental Chemical Engineering, vol. 6, no. 5, pp. 5920-5928, 2018.

[24] K. V. Kumar, K. Porkodi, and F. Rocha, "Langmuir-Hinshelwood kinetics - a theoretical study," Catalysis Communications, vol. 9, no. 1, pp. 82-84, 2008.

[25] H. N. Tran, S.-J. You, A. Hosseini-Bandegharaei, and H.P. Chao, "Mistakes and inconsistencies regarding adsorption of contaminants from aqueous solutions: a critical review," Water Research, vol. 120, pp. 88-116, 2017.

[26] S. K. Durrani, S. Naz, M. Mehmood, M. Nadeem, and M. Siddique, "Structural, impedance and Mössbauer studies of magnesium ferrite synthesized via sol-gel autocombustion process," Journal of Saudi Chemical Society, vol. 21, no. 8, pp. 899-910, 2017.

[27] M. Thommes, K. Kaneko, A. V. Neimark et al., "Physisorption of gases, with special reference to the evaluation of surface area and pore size distribution (IUPAC Technical Report)," Pure and Applied Chemistry, vol. 87, no. 9-10, pp. 1051-1069, 2015.

[28] J. De Laat and H. Gallard, "Catalytic decomposition of hydrogen peroxide by $\mathrm{Fe}(\mathrm{III})$ in homogeneous aqueous solution: mechanism and kinetic modeling," Environmental Science of Technology, vol. 33, no. 16, pp. 2726-2732, 1999.

[29] A. Cihanoğlu, G. Gündüz, and M. Dükkancı, "Degradation of acetic acid by heterogeneous Fenton-like oxidation over ironcontaining ZSM-5 zeolites," Applied Catalysis B: Environmental, vol. 165, pp. 687-699, 2015.

[30] M. Aleksić, H. Kušić, N. Koprivanac, D. Leszczynska, and A. L. Božić, "Heterogeneous Fenton type processes for the degradation of organic dye pollutant in water - the application of zeolite assisted AOPs," Desalination, vol. 257, no. 1-3, pp. 22-29, 2010.

[31] M. Pera-Titus, V. García-Molina, M. A. Baños, J. Giménez, and S. Esplugas, "Degradation of chlorophenols by means of advanced oxidation processes: a general review," Applied Catalysis B: Environmental, vol. 47, no. 4, pp. 219-256, 2004.

[32] M. Muruganandham, R. P. S. Suri, S. Jafari et al., "Recent developments in homogeneous advanced oxidation processes for water and wastewater treatment," International Journal of Photoenergy, vol. 2014, Article ID 821674, 21 pages, 2014. 
[33] M. Muruganandham, R. P. S. Suri, M. Sillanpää et al., "Recent developments in heterogeneous catalyzed environmental remediation processes," Journal of Nanoscience and Nanotechnology, vol. 14, no. 2, pp. 1898-1910, 2014.

[34] S. R. Pouran, A. R. A. Aziz, and W. M. A. W. Daud, "Review on the main advances in photo-Fenton oxidation system for recalcitrant wastewaters," Journal of Industrial and Engineering Chemistry, vol. 21, pp. 53-69, 2015.

[35] R. Yin, J. Sun, Y. Xiang, and C. Shang, "Recycling and reuse of rusted iron particles containing core-shell $\mathrm{Fe}-\mathrm{FeOOH}$ for ibuprofen removal: adsorption and persulfate-based advanced oxidation," Journal of Cleaner Production, vol. 178, pp. 441448, 2018.

[36] N. Farhadi, T. Tabatabaie, B. Ramavandi, and F. Amiri, “Optimization and characterization of zeolite-titanate for ibuprofen elimination by sonication/hydrogen peroxide/ultraviolet activity," Ultrasonics Sonochemistry, vol. 67, article 105122, 2020.

[37] F. Peng, R. Yin, Y. Liao et al., "Kinetics and mechanisms of enhanced degradation of ibuprofen by piezo-catalytic activation of persulfate," Chemical Engineering Journal, vol. 392, article 123818, 2020.

[38] M. E. Malefane, U. Feleni, P. J. Mafa, and A. T. Kuvarega, "Fabrication of direct Z-scheme $\mathrm{Co}_{3} \mathrm{O}_{4} / \mathrm{BiOI}$ for ibuprofen and trimethoprim degradation under visible light irradiation," Applied Surface Science, vol. 514, article 145940, 2020.

[39] M. Jiménez-Salcedo, M. Monge, and M. T. Tena, "Photocatalytic degradation of ibuprofen in water using $\mathrm{TiO}_{2} / \mathrm{UV}$ and g- $\mathrm{C}_{3} \mathrm{~N}_{4}$ /visible light: study of intermediate degradation products by liquid chromatography coupled to high-resolution mass spectrometry," Chemosphere, vol. 215, pp. 605-618, 2019.

[40] J.-C. E. Yang, B. Yuan, H.-J. Cui, S. Wang, and M.-L. Fu, "Modulating oxone- $\mathrm{MnO}_{\mathrm{x}} /$ silica catalytic systems towards ibuprofen degradation: insights into system effects, reaction kinetics and mechanisms," Applied Catalysis B: Environmental, vol. 205, pp. 327-339, 2017.

[41] W. Cao, Y. Yuan, C. Yang, S. Wu, and J. Cheng, "In-situ fabrication of g- $\mathrm{C}_{3} \mathrm{~N}_{4} / \mathrm{MIL}-68$ (In)- $\mathrm{NH}_{2}$ heterojunction composites with enhanced visible-light photocatalytic activity for degradation of ibuprofen," Chemical Engineering Journal, vol. 391, p. $123608,2020$. 